\title{
An Assessment of State-Legislative Research
}

\author{
Keith E. Hamm, Rice University
}

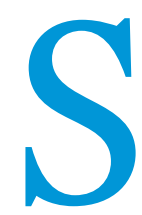
everal scholars have reviewed the growth and sophistication of the state-legislative literature in the past 40 years. The other six articles in this symposium attest to significant developments in multiple research areas. It is impossible in this short article to assess the entire subfield of state-legislative studies. Instead, I concentrate on four key areas: legislative professionalism, majority-party control, representation, and the impact of state constitutions on state-legislative behavior. Together, these four bodies of research demonstrate the ways that state-legislative scholars have used the comparative 50-state framework and the more innovative types of research designs to (1) create new concepts, (2) develop new theories, (3) provide rigorous tests of existing theories, and (4) open new frontiers of research.

Before discussing these four areas, a short history of the subfield development is provided. State-legislative research was in its infancy five decades ago. Rigorous theoretical development that accounted for significant institutional variation and the subsequent consequences was lacking. During the next few decades, comparative cross-state studies became more common. Scholars began to identify key components that differed across legislatures and why these differences mattered. In the past 15 years, progress in state-legislative research has accelerated. We now have more systematic comparative and historical knowledge about state legislatures (Squire 2014; Squire and Moncrief 2015). Research designs are more imaginative and rigorous. Given the relative ease of assembling information from websites, we now have a wealth of data to explore a broader range of questions. Scholars have overcome major methodological problems-for example, Shor and McCarty's (2011) use of National Political Awareness Test data.

\section{INTRODUCING AN ENTIRELY NEW CONCEPT: LEGISLATIVE PROFESSIONALISM}

The most significant research related to legislative organization at the state level has been done in the area of legislative professionalization. The accepted measure includes indicators of legislative staff or expenditures, session length, and legislator compensation with Congress as the baseline (Squire 1992; Squire 2007). State-legislative scholars did not borrow this important concept from congressional scholars. We created it (see Squire's article in this symposium).

An extensive literature demonstrates that the level of professionalization has an impact on the governing process
(Hamm, Hedlund, and Martorano Miller 2014; Squire and Hamm 2005). This includes but is not limited to legislative efficiency, electoral competition, legislative careers and ambition, partisan composition of legislatures, legislative leadership powers, role of committees, level and type of political representation, and impact of interest groups and governors. In other words, the structure and organization of state-legislative institutions matter.

\section{MULTI-METHOD APPROACHES TO THE STUDY OF MAJORITY-PARTY CONTROL}

State-legislative scholars currently use theories to guide their research initially developed to account for behavior in the US Congress. A strong argument can be made that the better test of these models is found where there is variation in the legislative configurations at the state level. Although several areas could be discussed (e.g., development of committee systems and ideal-point estimation), this article concentrates on if-and how-political parties matter in the legislature. The focus is on only one aspect of this debate: the extent to which the majority party controls the legislative agenda (Cox and McCubbins 1993). Three studies demonstrate the advantage of using comparative cross-legislative analysis, quasi- or natural experiments, or a combination of both approaches.

The comparative study uses survey data collected by the National Conference of State Legislatures and Anzia and Jackman's original survey of legislative clerks. Anzia and Jackman (2013) showed that in setting the legislative agenda, the majority's gatekeeping rights in committees and majority calendar rights vary significantly across the 99 statelegislative chambers. Are the agenda-setting capabilities of parties related to variation in majority roll rates across the states ${ }^{1} \mathrm{~A}$ key finding is that when majority-party leaders can block bills in the committee and going from the committee to the floor, the majority roll rates are significantly lower. The authors show convincingly that legislative rules affect the degree to which party leaders can control the agenda.

Cox, Kousser, and McCubbins (2010) demonstrated the value of using quasi-experiments to address the issue. They took advantage of an exogenous event of a voter-adopted rule change in the Colorado House over control of the legislative agenda. They also focused on an endogenous situation regarding variable majority-party control over the agenda in the California Assembly. In the case of the exogenous change that reduced the power of the majority party in the Colorado House to set the floor agenda, more majority-party 
rolls occurred and there was a more leftward tilt to the legislation. In the California Assembly, the rules governing fiscal committees grant the majority-party leaders control over a subset of bills. By having the majority-party leaders control the agenda for these bills-via what is known as the "Suspense File" arrangement-minority-party roll rates are significantly higher than when the majority-party does not control the agenda. Cox, Kousser, and McCubbins (2010, 809) collective partisan agenda. They measure both legislator and legislative-district ideal points. The findings were stunning: dyadic representation is generally absent (Masket and Noel 2012, 118). Legislators are almost always more ideologically extreme than the median voters in their district. Although these results are for only one state, they offer a technique that could be used in those states that allow voting on legislative referenda.

\section{A key finding is that when majority-party leaders can block bills in the committee and going from the committee to the floor, the majority roll rates are significantly lower. The authors show convincingly that legislative rules affect the degree to which party leaders can control the agenda.}

concluded: "Our results show that endowing majority leaders with greater agenda-setting powers (or removing those powers) does affect their ability to influence legislative outcomes."

The adoption of term limits in some states provides a natural experiment regarding legislative behavior when reelection is not possible (see Moncrief's article in this symposium). Clark (2012) used this opportunity to assess procedural party-cartel theory by comparing the behavior of three groups of legislators-term-limited legislators not seeking any other elective office, term-limited legislators seeking higher elective office, and non-term-limited legislators-in five legislatures. Clark concluded that the majority party has more control over procedural matters than policy matters; however, this capability is lost when the electoral connection is severed. Members who are being termed out and not seeking higher elective office are less disciplined when voting on procedural matters than their fellow legislators who are returning.

These three studies, using various research approaches, provide a strong argument that the majority party's ability to control the agenda can be affected by legislative rules and that the electoral connection is crucial to the party's ability to win on procedural as well as substantive votes.

\section{REVISITING A KEY CONCEPT: REPRESENTATION}

The concept of representation is one of the most studied in the legislative field. This section highlights how the use of more sophisticated measurement techniques, along with more innovative research methods, has significantly increased our understanding of the process.

\section{Measuring Constituent Policy Preferences}

Due to the lack of extensive data on citizens' policy preferences, state-legislative scholars have had to use less-thanperfect measures. Two new measurement techniques show great promise for future research. Masket and Noel (2012) solved the comparability problem by using legislative referenda in which legislators and voters cast votes on the same issue. Using these data allowed them to gauge the extent to which legislators are more in tune with a dyadic model with the district versus a partisan model that deals with the
Tausanovitch and Warshaw (2013) combined policy preferences from several surveys and estimated the average policy preferences of citizens in every state, congressional district, state-legislative district, and large city in the country. The authors adopted multilevel regression with poststratification. They used these data to assess the degree of policy representation. Using the estimates of district ideologies and statehouse members' ideal points in four states, they found a statistically significant relationship between district policy preferences and roll-call voting.

\section{Field Experiments}

One of the most significant changes in the study of representation involves the use of field experiments. Following are examples of how this approach can yield substantial benefits.

\section{Comparing Different Aspects of Representation}

One problem in studying the complex dimensional issues of representation as responsiveness is that previous studies typically focused on only one of the four dimensions (i.e., policy, service, allocation, and descriptive) set forth by Eulau and Karps (1977). Harden (2015) overcame the limitation of previous studies by comprehensively focusing on all four dimensions simultaneously. Because representation facilitates the attainment of reelection, legislators are strategic in their behavior about which aspects to accentuate. The creative research design uses two survey experiments administered online to state legislators. Harden tested various hypotheses involving institutional, district, and individual factors. A key finding was that state-legislative institutions matter. Legislators in more professional institutions with more staff and time prioritize service and allocation more highly than those in citizen legislatures.

Do legislators gain leeway on policy positions if they choose a more service-oriented style, as suggested by Fenno (1978)? A recent field experiment provided insight into this question (Butler, Karpowitz, and Pope 2012). The authors recruited Brigham Young University students who live in various districts throughout the United States to send letters 
to their members of Congress and state legislatures. Legislators were more responsive to service requests than to policy queries, and they became less responsive to policy requests as their margin of victory increased. Legislators who failed to prioritize service over policy did not do as well during the next election.

\section{Elites' Response to Constituents: Dismissing or Molding Constituents' Opinions}

We know that legislators do not conform to their constituents' preferences on some issues. A series of recent experiments by Butler and Dynes (2016) offered clues to this representationallinkage issue. Using three experiments, they concluded that elected officials discount the opinions of constituents with whom they disagree by assuming that those with opposing views are less informed about the content of the issue.

Instead of theorizing that legislators respond to constituents' opinions, a literature has developed offering a perspective that citizens in certain circumstances adopt the policy positions of politicians. Using two field experiments, Broockman and Butler (2017) provided a significant improvement in the empirical aspects of this debate by testing three theories: issue voting, elite persuasion, and position adoption. A finding worth considering for future research is that legislators can structure the views of their constituents on certain types of issues by merely stating their position.

\section{Legislators' Response to Constituency Requests}

Constituency service is a crucial component of representation. Three recent studies demonstrate the leverage that can be provided by field experiments on public officials. The first study revisits an issue that has produced mixed empirical to address underlying discrimination among state legislators, Butler and Broockman (2011) emailed legislators asking for assistance in registering to vote. Treatment conditions involved the name (i.e., an alias) of the requestor and partisanship signals. Overall, state legislators were less responsive to requests from blacks than from whites. A partial explanation is tied to Republicans being strategic in their responses. The principal conclusion, however, is that "legislators of every racial group engaged in significant levels of discrimination in favor of their racial group. Race still matters in American politics-both for elected officials and their constituents" (Butler and Broockman 2011, 473).

Is the bias in responsiveness a function of public officials' policy preferences? Mendez and Grose (2018) addressed this question in a field experiment in which legislators were randomly assigned to receive communications from Latino and white constituents. Those legislators who supported voteridentification laws were less likely to respond to Latino constituents.

My argument is simple. The use of new measurement techniques of constituents' opinions and field experiments, when taken together, significantly enhances our understanding of the representational process in the states.

\section{A NEW FRONTIER: CONSTITUTIONAL CONSTRAINTS}

I mentioned previously that theories developed by congressional researchers had been applied to state legislatures. A note of caution, however, is required. Most legislative theories assume that legislators can change the rules under which they operate without many legal constraints. Whereas this assumption is correct for the US Congress, state-legislative institutions can be constrained by their governing constitutions

\section{The use of new measurement techniques of constituents' opinions and field experiments, when taken together, significantly enhances our understanding of the representational process in the states.}

results over the years-namely, the relationship between the margin of electoral victory and subsequent responsiveness to requests for provision of constituency services. Dropp and Peskowitz (2012) contended that past research using surveys and interviews with legislators contains significant measurement error. They relied instead on information requests about a government program and voter registration to all members of the Texas legislature. They found convincing evidence that as the electoral security of a legislator increases, that legislator's responsiveness to constituent requests decreases. This study provides a template for future comparative work and shows the value of adopting new approaches to long-standing questions.

Two field experiments demonstrate how the question of race can be studied among elected officials. The findings provide insight into how discrimination can occur when the treatment conditions are merely names, locations, and policy preferences of legislators. Using a creative approach and statutes. Hence, to truly understand the role of state legislatures, we need to comprehend what might restrict their behavior.

A simple recounting of the differences across constitutions might prove useful for future researchers. It has been argued that constitutions may restrain the development of professionalization (Hamm, Hedlund, and Martorano Miller 2014). For example, legislators' compensation in $25 \%$ of the states is controlled by a non-legislative compensation committee or specified in the constitution. Regarding time in session, more than $56 \%$ of constitutions place a limit on the length of a session. More generally, in reading the legislative articles of all 50 state constitutions and the US Constitution, 309 different types of provisions were identified (Martorano Miller, Hamm, and Hedlund 2015). The US Constitution contains 12 provisions; only two states have fewer. The provisions include those that grant powers, restrict the power of the legislature, and mandate that the legislature undertake specific tasks. 
When we constructed a constitutional-restrictiveness measure [i.e., powers - (restrictions + mandates)], every state and the US Congress had a negative score, except for New Hampshire. In Vermont, the legislature has substantial freedom to conduct its business in the manner it chooses. In Texas, the legislature faces more limits on its ability to act. The Texas constitution contains numerous legislative-process provisions: legislative sessions are limited to 140 days and the types of issues that can be considered and what actions are appropriate during the various phases of the session are detailed. Also, the legislative process is restricted by numerous rules, including setting a two-thirds quorum, mandating germane amendments, and mandating deadlines for action. These factors should be considered in future research efforts.

\section{CONCLUSION}

To conclude, I make two final observations. First, we must rethink the development of US legislatures during the past 400 years. The first change is to acknowledge that the evolutionary line of American legislatures places colonial assemblies and the 13 original state legislatures as predecessors of the Constitutional Congress (Squire 2014). Rather than perceiving the original state legislatures as copying the structure and procedure of the US Congress, Squire $(2014,8)$-in his massive study of the institutional development of state legislatures from the seventeenth century to the twenty-first century-argued for a different developmental analysis:

Perhaps more controversial is the claim in chapter 3 that the original state legislatures were the models for the Congress created by the Constitution...in every elemental characteristicnumber and name of houses and the relationship between them, the legislature's ability to name its own leaders and adopt its own rules, and the power of the executive veto-the Congress under the Constitution closely resembled the original state legislatures. It bore no relationship to the Congress that existed under the Articles of Confederation, which was a unicameral chamber that fused legislative, executive, and judicial powers, and granted each state, not each legislator a vote.

Squire $(2014,87)$ went on to make the case that:

The rules and structures employed by the Confederal Congress lead to its failure (Wilson 1999). Those who wrote the US Constitution in 1787 recognized the problems and created a legislature modeled on the more successful state bodies.

More specifically, Squire stated (2014, 95):

The increasingly complex rules developed in Pennsylvania are particularly significant because they, along with those used in Virginia, largely influenced the rules subsequently adopted by the newly created US House and Senate (McConachie 1898, 10).

State legislatures are not simply smaller versions of the US Congress.
The second observation addresses the idea of constitutional constraints. The fact that many states have embedded legislative structures and procedures in their constitution has important implications for the study of state legislatures. "They create the playing field on which the political battles regarding public policy are fought, and they set the rules which govern how the public policy 'game' is played" (Martorano Miller, Hamm, and Hedlund $(2015,1471)$. The results are a far cry from the theories and realities of the US Congress.

\section{ACKNOWLEDGMENT}

I thank Reviewer \#1 for excellent suggestions. I incorporated language for both the section titles and a few sentences in the text.

\section{NOTE}

1. Majority roll rates typically are defined as the total number of times the majority party is rolled (i.e., loses the vote) divided by the total number of votes for a party.

\section{REFERENCES}

Anzia, Sarah F., and Molly C. Jackman. 2013. "Legislative Organization and the Second Face of Power: Evidence from U.S. State Legislatures.” Journal of Politics 75: 210-24.

Broockman, David E., and Daniel M. Butler. 2017. "The Causal Effects of Elite Position-Taking on Voter Attitudes." American Journal of Political Science 61: 208-21.

Butler, Daniel M., and David E. Broockman. 2011. "Do Politicians Racially Discriminate Against Constituents? A Field Experiment on State Legislators." American Journal of Political Science 55: 463-77.

Butler, Daniel M., and Adam M. Dynes. 2016. "How Politicians Discount the Opinions of Constituents with Whom They Disagree." American Journal of Political Science 60: 975-89.

Butler, Daniel M., Christopher F. Karpowitz, and Jeremy C. Pope. 2012. "A Field Experiment on Legislators' Home Styles." Journal of Politics 74: 474-86.

Clark, Jennifer Hayes. 2012. "Examining Parties as Procedural Cartels: Evidence from the U.S. States." Legislative Studies Quarterly 37: 491-507.

Cox, Gary W., Thad Kousser, and Matthew D. McCubbins. 2010. "Party Power or Preferences? Quasi-Experimental Evidence from American State Legislatures." Journal of Politics 72: 799-811.

Cox, Gary W., and Mathew D. McCubbins. 1993. Legislative Leviathan: Party Government in the House. Berkeley: University of California Press.

Dropp, Kyle, and Zachary Peskowitz. 2012. "Electoral Security and the Provision of Constituency Service." Journal of Politics 74: 220-34.

Eulau, Heinz, and Paul D. Karps. 1977. "The Puzzle of Representation: Specifying Components of Responsiveness." Legislative Studies Quarterly 2: $233-54$.

Fenno, Richard. 1978. Homestyle. Boston: Little, Brown.

Hamm, Keith E., Ronald D. Hedlund, and Nancy Martorano Miller. 2014 "State Legislatures." In Oxford Handbook of State and Local Government, ed. Donald Haider Markel, 293-318. Oxford, UK: Oxford University Press.

Harden, Jeffrey J. 2015. "Multidimensional Responsiveness: The Determinants of Legislators' Representational Priorities." Legislative Studies Quarterly 68: $155^{-84}$.

Martorano Miller, Nancy, Keith E. Hamm, and Ronald D. Hedlund. 2015. "Constrained Behavior: The Entrenchment of Legislative Procedure in American Constitutional Law." Albany Law Review 78: 1459-84

Masket, Seth E., and Hans Noel. 2012. "Serving Two Masters: Using Referenda to Assess Partisan versus Dyadic Legislative Representation.” Political Research Quarterly 65: 104-23.

Mendez, Matthew, and Christina R. Grose. 2018. "Doubling Down: Inequality in Responsiveness and the Policy Preferences of Elected Officials." Legisla tive Studies Quarterly 43: 457-91. 
Shor, Boris, and Nolan McCarty. 2011. "The Ideological Mapping of American Legislatures." American Political Science Review 105: 530-51.

Squire, Peverill. 1992. "Legislative Professionalization and Membership Diversity in State Legislatures." Legislative Studies Quarterly 17: 69-79.

Squire, Peverill. 2007. "Measuring State Legislative Professionalism: The Squire Index Revisited." State Politics and Policy Quarterly 7: 211-27.

Squire, Peverill. 2014. The Evolution of American Legislatures: Colonies, Territories, and States, 1619-2009. Ann Arbor: University of Michigan Press.
Squire, Peverill, and Keith Hamm. 2005. 101 Chambers: Congress, State Legislatures, and the Future of Legislative Studies. Columbus: The Ohio State University Press.

Squire, Peverill, and Gary Moncrief. 2015. State Legislatures Today: Politics under the Domes, Second edition. Upper Saddle River, NJ: Longman.

Tausanovitch, Chris, and Christopher Warshaw. 2013. "Measuring Constituent Policy Preferences in Congress, State Legislatures, and Cities." Journal of Politics 75: 330-42. 